\title{
IMPLEMENTATION OF LEGAL PROTECTION OF TOURIST IN FOLLOWING WHITEWATER RAFTING PACKAGE ATKNB HOLIDAY MEDAN
}

\author{
By: \\ Padriadi Wiharjokusumo $^{1)}$, Novita Romauli Saragih ${ }^{2)}$ \\ E-mail: knb.ministry76@gmail.com ${ }^{1)}$, novitaromauli12@ gmail.com ${ }^{2)}$ \\ Tourism and Hotel Academy of Darma Agung (APP-DA) ${ }^{1.2)}$
}

\begin{abstract}
Implementation of Legal Protection of Tourists, will not be separated who is responsible for an act to whom the act can be accounted for and whether anyone who commits an act where the consequences of the act can cause harm to people, can be accounted for by the maker. This research examines the implementation of legal protection of tourist in following whitewater rafting package at KNB Holiday Medan. This research was conducted through anempirical legal approach. The data source of this research was gained from the field study. Then analyzed using the qualitative analysis which depicts and dissects the significant information.The conclusion of this research wasthat the implementation of KNB Holiday's responsibility towards tourists in the event of things that are detrimental to consumers in practice is responsible for the extent of their profession or agreements that have been agreed with consumers of service users, namely strict liability against strict professional liability.
\end{abstract}

Keywords:implementation, responsibility, KNB Holiday.

\begin{abstract}
Abstrak
Implementasi Perlindungan Hukum Terhadap Wisatawan tidak akan terlepas siapa yang bertanggung jawab atas sesuatu perbuatan kepada siapa perbuatan dapat dipertanggung jawabkan serta apakah setiap orang yang melakukan suatu perbuatan dimana akibat dari perbuatannya tersebut dapat menimbulkan kerugian bagi orang, dapat dipertanggung jawabkan oleh sipembuat. Penelitian ini mengkaji implementasi perlindungan hokum terhadap wisatawan dalam mengikuti paket wisata arung jeram di KNB Holiday Medan. Penelitian ini dilakukan dengan menggunakan pendekatan hukum empiris. Sumber data penelitian ini diperoleh dari studi lapangan. Kemudian dianalisis menggunakan analisis kualitatif yang menggambarkan dan mengkaji informasi penting. Kesimpulan dari penelitian ini adalah bahwa implementasi tanggung jawab terhadap wisatawan di KNB Holiday Medan dalam hal yang merugikan wisatawan dalam praktiknya bertanggung jawab sebatas profesi mereka atau perjanjian yang telah disepakati dengan wisatawan sebagai konsumen pengguna jasa, yaitu tanggung jawab strict liability terhadap tanggung jawab strict professional liability.
\end{abstract}

Kata kunci: implementasi, tanggungjawab, KNB Holiday.

\section{INTRODUCTION}

In accordance with the deed of incorporation based on Law No.40 of 2007 concerning Limited Liability Companies (State Gazette No. 106 of 2007, supplement to State Gazette No.4756),KNB Holiday, has a consumer service business license covering:

a. Running a business travel agency services; 
b. Planning and packaging the components of the tour, which includes tourism facilities, tourist attraction attractions and other tourism services, especially those within the territory of Indonesia, in the form of tour packages;

c. Organizing and selling the tour packages by channeling through travel agents and or selling them directly to tourists;

d. Arranging the travel documents, including sales and / or ticket sales;

e. Providing and coordinating the tour guides;

f. Providing the tour guide services relating to tour packages, including the provision of tourist transport services;

g. Booking the accommodation, restaurants, convention venues and cultural performance tickets;

h. Organizing the incentive trips.

Based on the legal basis for the establishment of the company above, KNB Holiday has the right to conduct its business activities to serve consumers and consumers are entitled to obtain the services in accordance with what was promised and can also claim their rights if it is not fulfilled through legal channel. However, seeing from the implementation of the existing practices of activities of KNB Holiday, it doesn't only cover the above matters but also carries out other business activities such as:
a. Camping
b. Cycling
c. Outbound training
d. Paint ball
e. Tubing
f. Whitewater rafting

Specifically for Whitewater Rafting and Expedition, KNB Hoildayoffers a wide selection of adventure tour packages including:

a. 1 Day Visit To The Orangutan Feeding Platform In Bukit Lawang

b. 1 Day Whitewater Rafting Expedition

c. 2 Day Off Road Tour To Visit The Elephants In Tangkahan

d. 3 Day Tour To Bukit Lawang And Tangkahan

e. 5 Day Tour To Bukit Lawang And Tangkahan

f. 3 Day Trekking and White Water Rafting Expedition in Marike

g. 5 Day Overland Tour To Brastagi Volcanoes And Lake Toba

h. 3 Day Tour to Besitang for Elephant Trekking and Wildlife Spotting

i. 9 day sumatran wild Orangutan and Tiger Trek expedition

j. 8-10 Day Aceh to North Sumatra Jungle Trek

k. 2 Week Volunteer Wild Orangutan Research Project

In carrying out the above business activities, especially the whitewater rafting adventure tourism package on the Alas river which is the object of this research. KNB Holiday applies the provisions in the form of Standard Operating Procedures (SOPs) adopted from the International Rafting Federation (IRF) and Queensland Adventure Activity Standard to minimize or avoid any risk of accidents in every activity, for example in terms of corporate responsibility and tour guides.

Based on the description above the issue raised,how is the implementation of legal protection of tourist in following whitewater rafting package at KNB Holiday Medan?

\section{LITERATURE REVIEW}


The term "consumer protection" is related to legal protection especially in relation to the topic under discussion, namely the legal protection of tourist in following whitewater rafting package at KNB Holiday. Therefore, consumer protection contains legal aspects. The material that obtains protection is not just physical, but even more that its rights are abstract. In other words, consumer protection is actually identical to the protection provided by the law regarding consumer rights.

As conveyed by Fuadi (1994:184) the presence of a legal process, legal rules (regulators), legal instruments (remediumjuris) and law enforcement is the desire of the Indonesian people now, so that consumers, producers, and even the whole community will reap the rewards.

However, it cannot be denied that tourist as a party who uses the services of a Travel Bureau are often denied their rights. In Law Number 10 Year 2009 concerning Tourism, it is stated in article 20 that every tourist has the right to obtain:

a. Accurate information about tourist attractions;

b. Tourism services in accordance with standards;

c. Legal and security protection;

d. Health services;

e. Protection of personal rights; and

f. Insurance protection for high-risk tourism activities.

Whereas in article 62 of Law No. 8 of 1999 concerning consumer protection, it has been regulated regarding violations committed by business actors.

\section{RESEARCH METHODS}

This research is a type of empirical legal research. The empirical legal research is oriented towards primary data (results of field research). According to SoerjonoSoekanto and Sri Mamudji (1989: 12) empirical legal research is an approach carried out by field research by looking at and observing what is happening in the field.To support this empirical legal research,the normative legal research is also used by approaching the law in conducting a review of the legislation related tothe implementation of Legal Protection of Tourist.

In this process, the method used through interview techniques (field research) is then compiled and analyzed descriptively to the issues raised by the research problem. In accordance with these objectives, the authors take a sample to the source and have been determined beforehand, where the resource persons(respondents) must be competent and master the problems regarding the implementation of Legal Protection of Tourists in following the Rafting Adventure Tour Package in the Southeast Aceh on Alas river at KNB Holiday. The results of the interview are then processed and analyzed so that a conclusion can be drawn (Ibrahim, 2008:295).

\section{RESEARCH RESULT AND DISCUSSION}

a. Responsibilities of Corporate

The Rafting Adventure Company must ensure that every tour guide employed or involved in the rafting adventure tour package activities must have experience and skills in rafting and its safety activities including understanding and recognizing river and weather conditions as described in terms of: (Release of Responsibility Agreement on Whitewater Rafting Package Tour of KNB Holiday Medan). 
"The provider of river rafting adventure activities should ensure that leaders and guides employed or engaged by the provider in relation to river rafting adventure activities have the experience and skills to safely lead or guide the activity, regardless of the river and weather conditions. The provider should also ensure that leaders and guides fulfill their respective responsibilities as outlined below.

1) Staff selection,training and supervision

Providers should also include in their organizational procedures:

a) Details identifying the skills and experience required by leaders and policies to employ persons who have those skills and experience

b) Details of job descriptions identifying key tasks and responsibilities of rafting leaders and management, in relation to safety

c) Details of how the owner will ensure the leaders are medically and physically fit to work as rafting leaders

d) Details of the procedure to be followed by leaders and owners should a rafting leader choose to act or refuse to work on the grounds of compromised safety to themselves, other rafting leaders or passengers. It is recommended that this procedure clearly identify.

\section{b. Responsibilities of a Tour Guide}

The tour guide must take overall responsibility andcoordinating all rafting participants, leading and supervisingany rafting activity that aims to achieve group goalsor individual participants. The responsibilities of tour guides in the field according to Standard Operating
Procedures (SOP) made by KNB Holiday by adopting the Queensland Adventure Activity Standards are:(https://qorf.org.au/industry/australianadventure-activity-standard/)

1) working within the policies, procedures and activity standard operating procedures (SOPs) of the organizational stakeholders and land/water managers (where applicable);

2) confirming the activity plan (Section 4)

3) researching and planning for likely hazards, incidents and emergencies

4) confirming that an emergency strategy has been lodged with an appointed external contact;

5) checking the first aid kit and communication equipment before the activity

6) checking the raft and all group and personal equipment prior to departure and on return for wear, damage and improper inflation;

7) ensuring all loose equipment, containers and other objects are properly stowed and secured;

8) ensuring there are no loose loops or ends of rope or other tie down material

9) carrying out a full briefing session and ensuring that all participants and staff understand it (Section 5.2.1);

10) assessing that each participant's level of knowledge, ability and skill is appropriate for the difficulty and complexity of the activity, and that the equipment is adequate;

11) obtaining each participant's acknowledgement that the leader;

12) ensuring that participants and staff have completed all documentation, and that it has been collated;

13) ensuring there is sufficient space on the raft for all participants to be seated 
safely; sufficient participants are able to safely propel the raft so that the rafting leader can maintain control (in the case of oar rafts, there are sufficient oars and space to allow the rafting leader to control the raft);

14) ensuring that the message of minimal impact to the environment is conveyed and adhered to managing and minimising the activity's effect on the

15) ensuring that the group knows where to access safe drinking water;

16) environment (Sections 4.1.1 and 4.12);

17) conducting a practice session of required skills and ongoing coaching of technical skills;

18) managing last-minute checks, including weather and equipment checks;

19) taking a head count before, during (regularly) and immediately after the activity;

20) maintaining a constant awareness of the group's physical and psychological condition;

21) managing the group to avoid or minimize the effects of hazards;

22) complying with any land/water manager's requirements, including permits and approvals (Sections 4.1 and 4.3);

23) controlling the pace of the group and resting the group if necessary

24) maintaining observation of participants;

25) maintaining communication between the participants

26) facilitating the achievement of objectives (e.g. through a post-activity debrief), monitoring participant experience and following up with the group, delegating responsibility to any support personnel and ensuring that any vehicle used is suitable,

27) ensuring appropriate rescue procedures are followed in the event of an emergency, notifying external contacts when the group has completed the activity and returned safely, ensuring any incidents are managed, documented and reported, ensuring equipment is logged and packed away.

\section{Analysis of the Results of Field Interview Studies}

Based on the results of interviews conducted with several respondents namely; JutriSaragih, a tour guide who has worked for 5 years in the field of river adventures (whitewater rafting) on the Alas River at the Travel Bureau of KNB Holiday explained that where the company he works prioritizes security, safety, and comfort in service to tourists (Interview with JutriSaragih on May 2, 2019).

According to Jutri, the Alas River rafting adventure tour package is a super VIP adventure tour package (very impotent person). This can be seen from the price of the tour offered at a price of 450 US Dollars / pax for a 5 day 4 night package. Therefore all equipments (rafting gears) must meet international standards (the International Rafting Federation (IRF).

On the other hand Edi SatriaMunteh, is also a rafting adventure tour guide who has worked for more than 6 years, said that specifically for the Alas river rafting adventure tour packages have requirements that differ from other rivers such as the Bingei River, Binjei, Wampu River, Bukit Lawang. Both rivers can be floated down by anyone,meaning from children to parents even for those who do not have 
white water rafting skills. This is because the Bingei and Wampu rivers only have difficulty levels grade 11 and 111 levels.

While the Alas River is far more challenging. The level of difficulty can reach grade IV even to grade $\mathrm{V}$ and $\mathrm{V}$. This depends on the weather or season. In the dry season the difficulty level only reaches grade IV, but when the rainy season arrives the difficulty level will increase to grade $\mathrm{V}$ and $\mathrm{Vl}$.

Edi Satria further explained that tourists who will join the rafting adventure tour packages on the Alas River must meet various requirements as written on the risk assumption form and the personal responsibility agreement (Assumption of Risk and Release of Liability Agreement) or A.R.R:

a. Fill in the Assumption of Risk and Release of Liability Agreement or A.R.R form which explains that each participant understands and acknowledges that:

1) Rafting on the river will face a variety of both known and unanticipated risks, which can result in physical or emotional injury, paralysis, death, or damage to oneself, as well as luggage (property), or to third parties.

2) During the rafting adventure activities will face the ferocious spectacular rapids, participants can be blown, thrown, hit by the swivel, drifted and drowned.

3) When wading through rapids, participants can get hurt due to the slamming of hard objects in food and beverage cooler boxes, camera storage boxes, handy cams and others in the boat (raft).

4) The boat can be overturned due to hit a large rock, cliff wall, or inhaled by the swivel (eddy).
5) Accidents can also occur when getting on and off a boat.

6) When crossing the jungle, participants can be attacked by wild animals such as; tigers, bears, elephants, wild boar snakes and other wild animals.

7) When camping on the beach the participant can be washed away by a sudden, heavy flood.

8) The sun's heat can cause sunburn, nausea and headache.

9) And others as written in the Assumption of Risk and Release of Liability Agreement.

b. Approve and promise to accept and bear all risks of accidents that will occur during the rafting adventure activities;

c. Holding aadventure travel insurance that covers accident, damage to luggage and death.

d. Holding a certificate (certificate), explaining that the person involved in a similar adventure in grades IV, V, Vl.

e. Submitting a doctor's certificate explaining that the participant does not have a disease that endangers himself during the rafting adventure activities such as heart attacks, epilepsy, and others.

f. Complying all the provisions of nature conservation provided by forestry officials who accompany the participants during white water rafting adventures both on the river and while exploring the GunungLeuser National Park.

g. Obeying the instructions, cue, command, given by the tour leader and tour guide during the rafting adventure takes place.

Hekman, a US citizen who worked as a tour leader, represented 15 of his colleges 
when interviewed about the service standards and rafting equipment standards owned by KNB Holiday said,"So far so good, I personally appreciate what they're doing for my groups from the USA. Once in a year I bring tourists to Alas River, handled by KNB Holiday. I've been working with this company for almost 5 years. As I know they provide us with excellent service and the best quality gears as well. Up to now I don't have any complaint with them. I'm happy working with them. "

In addition, when asked about the Assumption of Risk and Release of Liability Agreement, which became the main requirements in following the rafting adventure tour package. $\mathrm{He}$ answered,"Well, it's normal, everywhere you go for whitewater rafting expedition in this world. Even if you go to the USA for example doing rafting in Grand Canyon or Colorado river you will be given the form of Assumption of Release Liability to be signed that you agree to accept all existing risks.

On the other hand, Junaidi, a Gunung Leuser national park forestry police officer based in Kuta Cane, Southeast Aceh, is often tasked with assisting foreign tourists in whitewater rafting on the Alas River and trekking in the GunungLeuser National Park. When asked regarding the implementation of legal responsibilities given by the Travel Bureau in this case KNB Holiday.

"Pretty good, last December 2019. I was assigned by my office to accompany a group of tourists from Germany as many as 12 people. In December, usually in the Alas River region, the rainfall is quite high so that the level of difficulty of the river for rafting reaches grade V or even V1. My inflatable boat hit the rocky cliff wall, injuring my left arm. In short, I had a broken arm.

The accident happened on the first day, then I was taken to get treatment at Kuta Cane hospital. Then I was referred to Elisabeth Medan Hospital. KNB Holiday took care of all the administration documents needed to claim medical expenses from an insurance company that was previously paid by KNB Holiday. I was truly satisfied with the service provided by KNB Holiday, "said Junaidi (Interviewed with Junaidi on May 15, 2019).

Meanwhile Limbeng, Director of KNB Holiday Medan explained about accidents that occured during rafting adventure activities. According to him $99 \%$ of accidents occur on land rather than in rivers. KNB Holiday, which operates from the beginning of 2005 until 2019, only had an accident that struck the Gunung Leuser Kuta Cane National Park police officer, Southeast Aceh in 2017.

To reduce and even avoid accidents that will occur when rafting on the Alas riverKNB Holiday does the following: (Interviewed with Limbeng on May 15, 2019).

1. Providing the international standard rafting gears as stipulated by the International Rafting Federation.

2. Assigningthe tour guides who are able to speak foreign languages according to the origin of tourists, for example guides in English, German, French, Spanish, Italian, Japanese and others. This is important to avoid miscommunication, so language misunderstanding does not occur, accidents can be avoided. 
3. Assigning a tour guide who is licensed and competent in his field and has experience leading a group of graduates on the river who have a level of difficulty grade IV, V at least 5 years.

4. Requiring the overseas business partners such as the United States, Germany, Japan, the Netherlands and other countries to include tour leaders from countries of origin. Thus the local guide is only a companion. This rule only applies to the Alas river only.

When asked why in Indonesia there are so many rafting accidents that have led to the deaths of several rafting participants.Limbengexplained that it did not only happen in Indonesia, but also abroad such as the United States, Australia, Canada and other countries. Generally these accidents occur not from commercial packages organized by the Travel Bureau, but amateurs who have not mastered the technology and techniques and rafting skills. For example, at the recent progowhich left 2 participants dead.

Learning from some accidents that often occur with rafting participants. According to Limbeng, both the central and regional governments should make regulations or laws governing the implementation of adventure activities in the wild like in the State of Queensland Australia. There they have a law governing adventure activities called the Adventure Activity Act.

So, unlike in Indonesia anyone can operate the rafting activities that cause various accidents, including in Sumatra, especially on the Alas river. We often find local guides who don't work under the auspices of the Travel Bureau selling rafting adventure tourism packages to foreign tourists using makeshift rafting equipment. They only use old tires (tubes) instead of inflatable boat, without using safety equipment such as helmets, life jackets, and other rescue equipment (safety equipment). "This really jeopardizes the safety of the foreign tourists they guide. This is what the local government must regulate to maintain the image of Indonesian tourism in the international world, "said Limbeng with a concerned tone.

\section{CONCLUSION}

Based on the above discussion it can be concluded that theimplementation of KNB Holiday'sresponsibility towards tourist in the event of things that are detrimental to consumers in practice is responsible for the extent of their profession or agreements that have been agreed with consumers of service users, namely strict liability against strict professional liability.

\section{REFERENCES}

Cronin, P.M. 2004. Foreign Aid.Dalam Cronin, A.K. and Ludes, J.M. (Ed.).Attacking Terrorism: Elementsof a Grand Strategy. Washington, D.C.: Georgetown University Press.

Decrop. A. 1999. Tourists' DecisionMaking and Behavior Processes.DalamPizam, A. and Mansfeld, Y.(Ed.).Consumer Behavior in Travel and Tourism. New York: The Haworth Hospitality Press.

Fuadi, Munir, 1994, HukumBisnisdalamTeoridanPrakte kBuku II, PT. Citra AdityaBakti, Bandung. 
Hall, C.M. and Page, S.J. 1999. The Geography of Tourism \& Recreation: Environment, Place and Space. Oxon(UK) and New York (USA): Routledge.

Ibrahim,Johny.TeoridanMetodologiPenelit ianHukum, Surabaya: Bayumedia, 2008.

Lelieur, I. 2003. Law and Policy of Substantial Ownership and Effective Control of Airlines: Prospects forChange. Hants (England): Ashgate Publishing Limited: 68.
Kunkel, L.M. 2008.International Tourism Policy and the Role of Governments in Tourism in the Context ofSustainability. Norderstedt (Germany): GRIN Verlag.

Soekanto, dan Sri Mamudji, 2006.PenelitianHukum, Jakarta: Raja GrafindoPersada. 